Article

\title{
Do Habitats Show a Different Invasibility Pattern by Alien Plant Species? A Test on a Wetland Protected Area
}

\author{
Francesco Liccari ${ }^{1,2, *}$, Miris Castello ${ }^{1}$, Livio Poldini ${ }^{1}$, Alfredo Altobelli ${ }^{1}$, Enrico Tordoni ${ }^{1}{ }^{1}$, \\ Maurizia Sigura ${ }^{2} \mathbb{D}$ and Giovanni Bacaro ${ }^{1}$ (D) \\ 1 Department of Life Sciences, University of Trieste, Via L. Giorgieri 10, 34127 Trieste, Italy; \\ castello@units.it (M.C.); poldini@units.it (L.P.); altobell@units.it (A.A.); etordoni@units.it (E.T.); \\ gbacaro@units.it (G.B.) \\ 2 Department of Agricultural and Environmental Sciences, University of Udine, Via delle Scienze 206, \\ 33100 Udine, Italy; maurizia.sigura@uniud.it \\ * Correspondence: francesco.liccari@phd.units.it
}

Received: 8 May 2020; Accepted: 3 July 2020; Published: 5 July 2020

\begin{abstract}
Biological invasions are deemed to be the second most important global driver of biodiversity loss, right behind habitat destruction and fragmentation. In this study, we aimed at testing if community invasibility, defined as the vulnerability to invasion of a community, could be associated with the characteristics of a given habitat, as described by the composition and structure of its native species. Based on a probabilistic sampling of the alien flora occurring in the temperate wetland Lake Doberdò (Friuli Venezia Giulia region, NE Italy) and using a null-model-based approach, the observed occurrence of Invasive Alien Species (IAS) within sampling units was randomized within habitats. While testing the degree of invasibility for each habitat within the wetland, our null hypothesis postulated that habitats are equally invaded by IAS, as IAS can spread homogeneously in the environment thanks to their plasticity in functional traits that makes them able to cope with different ecological conditions. The obtained results comparing observed IAS frequencies, abundance and richness to those obtained by the null model randomizations show that, for all habitats, invasion was selective. Specifically, a marked preference for habitats with an intermediate disturbance level, a high nutrients level and a medium-high light availability was observed, while an avoidance was detected for habitats characterized by lower levels of nutrients and light availability or extreme conditions caused by prolonged submersion. This method allows us to provide useful information using a simple-to-run simulation for the management of the IAS threat within protected areas. Moreover, the method allows us to infer important ecological characteristics leading to habitat invasion without sampling the environmental characteristic of the habitats, which is an expensive operation in terms of time and money.
\end{abstract}

Keywords: alien species; biodiversity; Lake Doberdò; Natura 2000 Network; occurrence probability; randomization; null model

\section{Introduction}

Biological invasions are deemed to be the second most important global driver of biodiversity loss, right behind habitat loss and fragmentation [1-3]. Indeed, the introduction and spread of Invasive Alien Species (hereafter IAS) $[4,5]$ have heavy repercussions on ecosystems, leading to negative impacts on native species, habitats, landscape, ecosystem production, naturalistic value, human health and the economy [6-9]. For these reasons, research interest on biological invasions has exponentially increased in recent years $[10,11]$. 
The success of IAS in their non-native ranges is claimed to be an effect of interactions among several mechanisms, divided into three main groups of factors: propagule pressure, habitat invasibility and species invasiveness [12-19]. Propagule pressure represents a composite measure of the number of individuals released into the introduction area [20]; it incorporates estimates of the absolute number of individuals involved in any one release event (propagule size) and the number of discrete release events (propagule number) [21]. Habitat invasibility is a property of recipient ecosystems and depends on the features that may determine their vulnerability to invasion, which, in turn, is potentially determined by the level of disturbance, the competitive abilities of the native species and their resistance to disturbance along with assembly mechanisms of the recipient community [22]. In this context, the rule that determines how the native community is assembled is also related to the occupied and available niche space in a given community [23,24], for example, in tropical communities there is low space availability, due to the presence of fast-growing multilayered vegetation that makes them resistant to invasions [25], while deforested mesic habitats with frequent disturbances present a higher rate of invasion because of greater niche availability [26-28]. It is well-known that the success of IAS depends on biotic factors such as competition or predation with native species, features of the native communities, and also on abiotic factors such as the availability of nutrients and light, as well as the presence of anthropogenic disturbance and environmental instability, which influence the available niche space [29]. Species invasiveness, namely the features that are consistently associated with the ability of IAS to invade, can be identified from comparative metrics between invasive and non-invasive alien species, such as those related to photosynthetic efficiency, the use of water and resources, reproduction and dispersal abilities. In addition, species invasiveness is also related to residence time (i.e., the time since the introduction of a taxa to a new area) and taxonomic affiliation (some taxa are more competitive than others due to phylogenetic background) [30]. In the last decade, research efforts have often focused on understanding species functional characteristics that may enhance their invasiveness, such as rapid reproduction and growth, high dispersal ability, and ecological plasticity [10,15,24,31-33]. Accordingly, it has been postulated that it is more multiple suites of traits that could explain invasion success in different environments [34-36], rather than a single dominant trait.

Even though several studies already investigated how to predict invasion success through the analysis of those factors related to species invasiveness [24,37-39], less attention has been paid to habitat properties' underlying community invasibility $[40,41]$. Invasibility has been studied mainly on a large scale, with data suffering from a reduced accuracy being aggregated from varying sources [42-44] and using rough environmental characteristics [45-47], whereas the smaller (local) scale has been substantially neglected $[48,49]$.

To complete the picture, IAS have been largely studied in human-altered and urbanized environments, which are known to be prone to biological invasions $[4,5,16,18,50,51]$, while less information is available for more natural and undisturbed habitats. An increasing number of studies [19,52-54] reported that even Protected Areas (hereafter PAs) can be seriously affected by IAS. Nevertheless, temperate wetland PAs are underrepresented in the invasive plant literature [55]. Wetlands are vulnerable ecosystems that are extremely important for the maintenance of biodiversity, as they are peculiar environments, a source of a rich plant and animal diversity. Wetlands are among the most disturbed and exploited ecosystems; they have been continuously subjected to the anthropic pressure, resulting in a dramatic decline during the last decades, especially across Europe, due to extensive habitat destruction and fragmentation [56-58]. This makes them more vulnerable and at greater risk of biological invasion considering that several studies highlight notable gaps for the long-term maintenance of biodiversity in wetland PAs [58,59].

These environments are usually characterized by marked vegetation zonation, associated with strong environmental gradients, dictated primarily by hydrology [60]. The hydrological regime of wetlands determines the distribution of different communities that are strictly linked to the presence of the water, causing a selective distribution of plant species on the basis of their capacity to tolerate submersion and/or dry periods. This vegetation zonation permits hosting numerous species, 
including rare and endemic ones, in relatively small areas; moreover, wetlands act as ecological sinks, accumulating nutrients transported by water, and, for this reason, they can also be more susceptible to IAS invasion [61,62].

In this study, we analyzed the possible effect of habitat features on community invasibility on a temperate wetland in NE Italy using null models. Specifically, we aimed at estimating the degree of invasibility for each habitat within the wetland PA. Our null hypothesis postulated that IAS presented a plasticity able to cope with differences in biological and environmental habitat characteristics, allowing them to spread without exclusive preferences; in other words, we expect them to be randomly spread across the wetland PA.

\section{Materials and Methods}

\subsection{Study Area}

The study was carried out at Lake Doberdò (Figure 1, Lat. 45.831574, Long. 13.562023), a karstic lake in north eastern Italy. It is part of the regional natural reserve "Laghi di Doberdò e Pietrarossa" and is included in the Natura 2000 network (SAC-IT3340006/SPA-IT3341002).

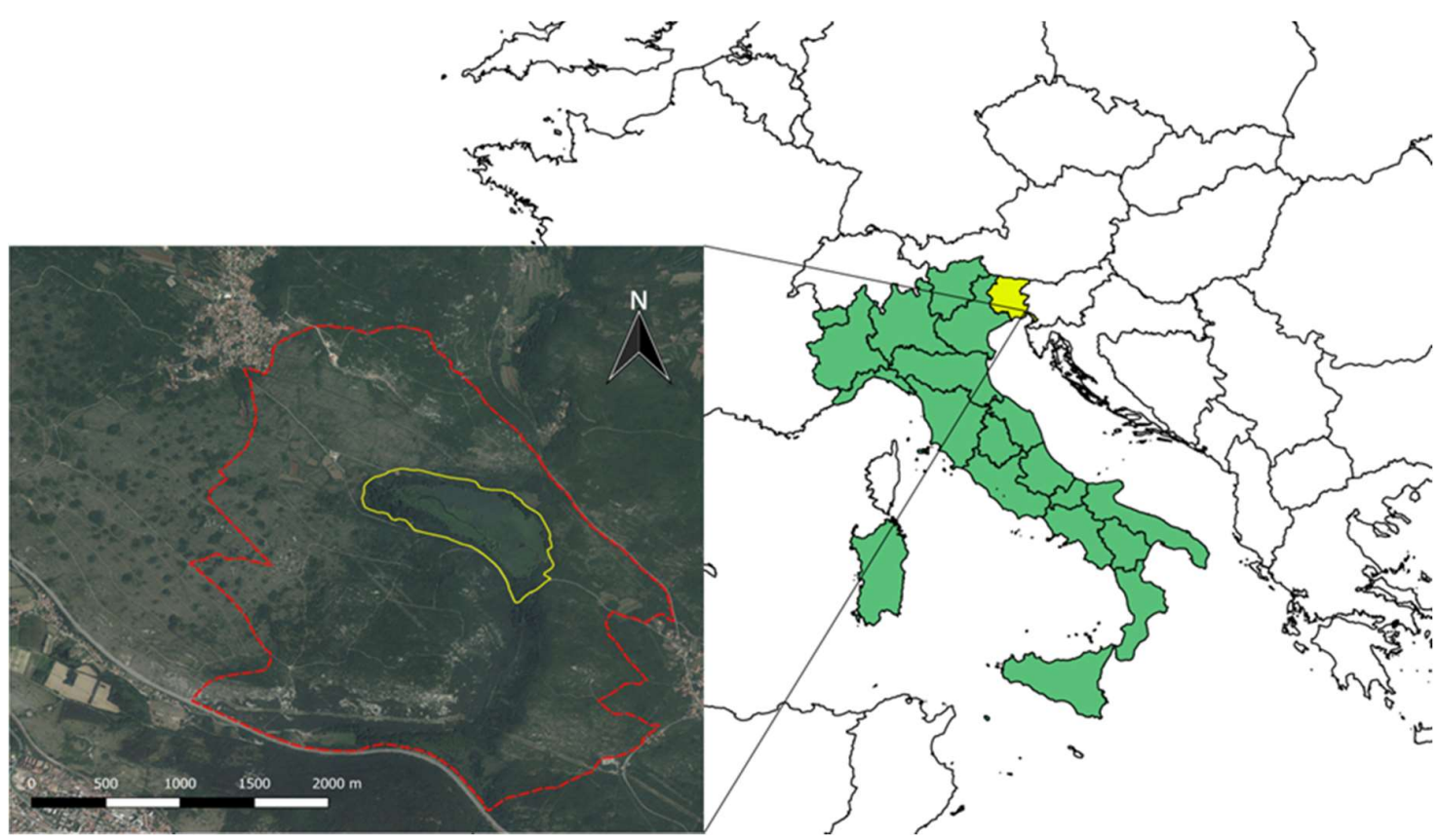

Figure 1. Location of the study area (yellow border) within the Regional Natural Reserve "Laghi di Doberdò e Pietrarossa" protected area (red dashed border).

The study area (ca. $65 \mathrm{ha}$ ) includes the lake and all the surrounding vegetation directly dependent on the presence of lake water, including the meso-hygrophilous one.

Bioclimate is temperate with lower meso-temperate thermotype and lower humid ombrotype, with relatively warm summers and dry and cool winters. The verage annual rainfall is around $1200 \mathrm{~mm}$. The mean annual temperature is $15^{\circ} \mathrm{C}$, with an average temperature of $5^{\circ} \mathrm{C}$ in January (coldest month) and $23^{\circ} \mathrm{C}$ in July (warmest month) (source: https://www.meteo.fvg.it; reference period: 1999-2018).

The study area is characterized by a complex geomorphology. It consists of a thick succession of limestone and subordinately dolomitic rocks, dated between the Lower Cretaceous (Aptiano) and the lower Eocene; the platform deposits are surmounted by turbidite deposits (flysch) [63-65]. The soils of the study area are classified as "red soils", e.g., clayey or silty-clayey soils that cover the calcareous or dolomitic substrates with variable thicknesses, filling particular fractures and areas with depressed morphology [66]. 
Lake Doberdò is a karst lake with a typical peculiar hydrology: it has no superficial inflow or outflow; the superficial runoff is near zero and the water feed mainly comes from the underground waters [67]. The water fills the lake emerging through karst springs located on the north-western side and disappears through the swallow holes on the eastern side of the lake. The lake feeding is mainly due to the underground flows of the Isonzo river and the precipitations, recharging the karst groundwater $[65,68,69]$. The water level of the lake is extremely variable throughout the year, leading to a significant change in the extension of the lake surface area, from $200 \mathrm{~m}^{2}$ during dry periods to $400,000 \mathrm{~m}^{2}$ during wet periods [70].

The vegetation of the lake is characterized, starting from the center of the lake and going outwards, by aquatic communities (dominated by submerged and floating-leaved rooted plants, such as Potamogeton spp., Myriophyllum spp. and Nuphar lutea), by helophytic marsh vegetation dominated by tall sedges (Carex elata) and common reeds (Phragmites australis); behind these, a thin strip of mud soil along the lake shore hosts hygro-nitrophilous herbaceous communities. The zonation is completed toward the lake shores and landwards by hygrophilous willow shrubs and woods (with Salix cinerea, Salix alba), and a meso-hygrophilous woodland with the field elm (Ulmus minor), black poplar (Populus nigra) and narrowed-leaved ash (Fraxinus angustifolia subsp. oxycarpa), with its mantle with Ulmus minor and Paliurus spina-christi.

\subsection{Sampling Design and Data Collection}

The identification of the habitats occurring in the study area was based on the phytosociological analysis of plant communities, following the approach adopted in modern European habitat classifications [71-74]. According to a preliminary vegetation survey of the area, carried out in 2015, 33 plant communities were classified according to the phytosociological approach [75-77]. Due to the scarce extension of some communities $\left(<1000 \mathrm{~m}^{2}\right)$ or to the small-scale heterogeneity in communities' spatial arrangements in some areas (where complex vegetation mosaics were present), only 20 vegetation types were effectively mapped (Figure S1) and considered in this study as different habitat units (Table 1).

Table 1. Description, extent and number of sampled plots referring to the vegetation types of the wetland protected area (PA) included in the main habitats.

\begin{tabular}{|c|c|c|c|}
\hline Habitat Type & Vegetation Type & Area (ha) & N. Plot \\
\hline \multirow{3}{*}{$\begin{array}{c}\text { Aquatic vegetation } \\
\text { (Lemnetea minoris and Potametea pectinati) }\end{array}$} & $\begin{array}{l}\text { Submerged communities in standing water in small } \\
\text { channels (Lemnion trisulcae, Potamion pectinati) }\end{array}$ & 0.15 & 4 \\
\hline & $\begin{array}{l}\text { Submerged communities in flowing water } \\
\text { (Potamion pectinati, Batrachion fluitantis) }\end{array}$ & 0.80 & 4 \\
\hline & $\begin{array}{c}\text { Submerged and floating-leaved communities in } \\
\text { pools (Nymphaeion albae, Potamion pectinati, } \\
\text { Ceratophyllion demersi) }\end{array}$ & 1.51 & 5 \\
\hline \multirow{8}{*}{$\begin{array}{c}\text { Marsh vegetation } \\
\text { (Phragmito australis-Magnocaricetea elatae) }\end{array}$} & $\begin{array}{c}\text { Community dominated by Schoenoplectus lacustris } \\
\text { (Scirpetum lacustris) }\end{array}$ & 1.33 & 4 \\
\hline & Phragmites australis reedbed (Phragmitetum australis) & 9.99 & 10 \\
\hline & $\begin{array}{l}\text { Community dominated by Eleocharis palustris } \\
\text { (Eleocharitetum palustris) }\end{array}$ & 0.13 & 4 \\
\hline & $\begin{array}{l}\text { Community dominated by Persicaria amphibia and } \\
\text { Persicaria hydropiper (Polygonetum hydropiperis) }\end{array}$ & 1.03 & 4 \\
\hline & Carex elata sedge beds (Caricetum elatae) & 12.40 & 13 \\
\hline & Carex vesicaria sedge beds (Caricetum vesicariae) & 0.74 & 4 \\
\hline & $\begin{array}{c}\text { Helophyte mosaic } \\
\text { (Phragmitetalia, Magno-Caricetalia) }\end{array}$ & 0.63 & 4 \\
\hline & $\begin{array}{c}\text { Community dominated by Sparganium erectum } \\
\text { (Glycerio-Sparganietum neglecti) }\end{array}$ & 0.18 & 4 \\
\hline $\begin{array}{l}\text { Lake shore herbaceous vegetation } \\
\text { (Agrostietea stoloniferae and } \\
\text { Bidentetea tripartitae) }\end{array}$ & $\begin{array}{l}\text { Communities dominated by Agrostis stolonifera and } \\
\text { Rorippa sylvestris, community dominated by Bidens } \\
\text { tripartita and Persicaria hydropiper } \\
\text { (Potentillion anserinae, Bidention tripartitae) }\end{array}$ & 2.97 & 7 \\
\hline
\end{tabular}


Table 1. Cont.

\begin{tabular}{|c|c|c|c|}
\hline $\begin{array}{l}\text { Willow shrublands and woodlands } \\
\text { (Alnetea glutinosae and Salicetea purpureae) }\end{array}$ & $\begin{array}{l}\text { Community dominated by Salix cinerea } \\
\text { (Frangulo alni-Salicetum cinereae) } \\
\text { Community dominated by Salix alba } \\
\text { (Salicetea purpureae) }\end{array}$ & 1.13 & 6 \\
\hline \multirow{3}{*}{$\begin{array}{l}\text { Meso-hygrophilous shrublands and forests } \\
\text { (Rhamno catharticae-Prunetea spinosae and } \\
\text { Salici purpureae-Populetea nigrae) }\end{array}$} & $\begin{array}{c}\text { Shrub community with Ulmus minor and Paliurus } \\
\text { spina-christi (Berberidion vulgaris) }\end{array}$ & 3.63 & 8 \\
\hline & $\begin{array}{c}\text { Meso-hygrophilous forest dominated by Ulmus } \\
\text { minor and Populus nigra } \\
\text { (Salici purpureae-Populetea nigrae) }\end{array}$ & 14.35 & 15 \\
\hline & $\begin{array}{l}\text { Meso-hygrophilous forest dominated by Ulmus } \\
\text { minor and Fraxinus angustifolia subsp. oxycarpa } \\
\text { (Salici purpureae-Populetea nigrae) }\end{array}$ & 4.42 & 9 \\
\hline \multirow{2}{*}{$\begin{array}{l}\text { Nitrophilous forests } \\
\text { (Robinietea) }\end{array}$} & $\begin{array}{l}\text { Robinia pseudoacacia forest with Lamium orvala } \\
\text { (Lamio orvalae-Sambucetum nigrae) }\end{array}$ & 0.71 & 4 \\
\hline & $\begin{array}{l}\text { Robinia pseudoacacia forest } \\
\text { (Bryonio dioicae-Sambucetum nigrae) }\end{array}$ & 2.12 & 5 \\
\hline Plantations & Hybrid poplar plantations & 1.56 & 5 \\
\hline
\end{tabular}

IAS occurrences within the 20 vegetation types were sampled by means of a probabilistic sampling approach. Specifically, a stratified random approach was adopted using vegetation types as homogeneous strata. For each vegetation type identified, squared sampling units (hereafter plots) of $1 \mathrm{~m}^{2}$ were randomly selected, with their number proportional to the total area occupied by the vegetation type. The number of plots was selected proportionally to the area of the communities as follows: 4 plots for all the communities with an extension up to 1.5 ha and 1 plot was then added every 0.7 ha up to a total extension of $5 \mathrm{ha}$; for communities bigger than $5 \mathrm{ha}$, the proportion $1 \mathrm{plot} / \mathrm{ha}$ was used. This sampling design was chosen to ensure the best compromise for representing small communities without oversampling the larger ones, thus maintaining a good compromise between statistical robustness and sampling effort. A total of 123 plots were sampled within the whole study area. We used such a small plot size $\left(1 \mathrm{~m}^{2}\right)$ in order to reduce the margin effect due to the scarce extension and jagged shape of some vegetation types.

The plots were materialized in the field and only IAS abundance was recorded within each plot, measured as percent cover based on visual estimation. The data were collected during the late summer-autumn 2015. The nomenclature, taxonomy and classification of the invasion status of naturalized and invasive alien plant species follow Galasso et al. [78], and the syntaxonomic nomenclature of the plant communities up to the level of alliance follows Biondi et al. [79]. All alien species have been included in the null model analysis irrespective of their invasion status. Alien plants occurring in only 1 plot were excluded from further analyses.

\subsection{Statistical Analyses}

Considering the limited dimension as well as the similar ecological value of certain vegetation types, we merged, for the following statistical analyses, the 20 vegetation types in 7 main habitats that reflect the hierarchical phytosociology classification to the class level. In particular, the following habitats were obtained (Table 1): aquatic vegetation (Lemnetea minoris and Potametea pectinati), helophytic marsh vegetation (Phragmito australis-Magnocaricetea elatae), lake shore hygro-nitrophilous herbaceous vegetation (Agrostietea stoloniferae and Bidentetea tripartitae), hygrophilous willow shrublands and woodlands (Alnetea glutinosae and Salicetea purpureae), meso-hygrophilous shrublands and forests (Rhamno catharticae-Prunetea spinosae and Salici purpureae-Populetea nigrae), anthropogenic neophytic nitrophilous forests (Robinietea) and plantations (hybrid poplars).

To determine if the distribution, abundance and richness of IAS in the main habitats were significantly different from random expectation, we used a simulation approach based on Monte Carlo randomization [80]. The randomization is designed to produce a pattern that would be expected in the absence of a particular ecological mechanism [81]. To the best of our knowledge, this is the first attempt 
to use null models to test IAS distribution in relation to habitat invasibility, thus drastically reducing the amount of data required to test the null hypothesis, compared, for example, to correlative studies.

A similar approach was used by Bajocco and Ricotta [82] to identify land-cover types where fire incidence was higher (preferred) or lower (avoided) than expected from a random null model. This method was originally designed to study resource selection by animals $[83,84]$. Bajocco and Ricotta [82] considered fire as an "herbivore" with variable preferences for different resources (i.e., land-cover types); we considered IAS and habitats in the same way. The effect of the method was that the random frequencies were only dependent on the habitat extension, i.e., larger areas have higher probability to have a IAS.

Observed occurrences for each IAS in the sampled plots were randomly reassigned to the 7 habitats by the simulation, so that the probability of the species to be assigned to a given habitat was proportional to the area of that habitat itself. The null hypothesis was that IAS were randomly distributed in the study area while the alternative hypothesis was that IAS were clustered (or absent) according to the habitat type. Comparing the result of 9999 randomizations to the observed occurrence data, we evaluated the probability (pseudo $p$-value) that observed occurrences were significantly different from those of the simulations. For each habitat, $p$-values (two-tailed test, $\alpha=0.05$ ) were calculated as the proportion of Monte-Carlo-derived values that were as low or lower (or as high or higher) than the real ones. The same method was also applied for the randomization of IAS abundances.

On the basis of the IAS frequencies resulting from the null model simulations, we also calculated the IAS random richness for every habitat, reshuffling 9999 times the matrix assembled with the random frequencies of each IAS per habitat (keeping the IAS probability resulting from the null model fixed). In this case, the null hypothesis was that the observed IAS richness per habitat was not different from the one resulting from the simulated one.

\section{Results}

\subsection{Description of the Collected Floristic Data}

A total of 12 alien species in the 123 plots were sampled. Among them, 11 are invasive (Ailanthus altissima (present only in one plot, discarded from the null model simulations), Ambrosia artemisiifolia, Amorpha fruticosa, Bidens frondosa, Cuscuta campestris, Elodea nuttallii, Oxalis stricta, Parthenocissus quinquefolia, Robinia pseudoacacia, Vitis $\times$ ruggerii, Xanthium italicum) and one naturalized (Bidens vulgata).

Concerning life forms, there is a prevalence of perennial species (seven species), while annual species are 5. Species mainly originated from North America (10).

The most abundant IAS was B. frondosa, collected in $48.78 \%$ of the total sampled plots (60 out of 123), followed by B. vulgata and X. italicum, both collected in $16.26 \%$ of total sampled plots (20 out of 123). Overall, the average number of IAS per plot was $1.20 \pm 1.29$ (mean \pm SD), while the average number of IAS per plot within each habitat was: $0.69 \pm 0.48$ for aquatic vegetation, $1.13 \pm 1.06$ for marsh vegetation, $4.29 \pm 0.95$ for lake shore herbaceous vegetation, $1.4 \pm 1.07$ for willow shrublands and woodlands, $0.78 \pm 1.01$ for meso-hygrophilous shrublands and forests, $0.67 \pm 0.87$ for nitrophilous forests and $2.2 \pm 0.45$ for plantations.

\subsection{Null Model Simulations}

The null models' results are shown in Tables 2 and 3. 
Table 2. For each habitat type, the observed frequencies (expressed as \%) of the Invasive Alien Species (IAS) are shown with the 95\% confidence intervals (C.I.) obtained from 9999 Monte Carlo simulations. In bold and with asterisks, the observed IAS frequencies are significantly different than expected (*** $p<0.001 ; * * ~<<0.01$; $* p<0.05)$.

\begin{tabular}{|c|c|c|c|c|c|c|c|c|c|c|c|c|}
\hline Habitat Type & & $\begin{array}{c}\text { Ambrosia } \\
\text { artemisifolia }\end{array}$ & $\begin{array}{l}\text { Amorpha } \\
\text { fruticosa }\end{array}$ & $\begin{array}{c}\text { Bidens } \\
\text { frondosa }\end{array}$ & $\begin{array}{l}\text { Bidens } \\
\text { vulgata }\end{array}$ & $\begin{array}{c}\text { Cuscuta } \\
\text { campestris }\end{array}$ & $\begin{array}{c}\text { Elodea } \\
\text { nuttallii }\end{array}$ & Oxalis stricta & $\begin{array}{c}\text { Parthenocissus } \\
\text { quinquefolia }\end{array}$ & $\begin{array}{c}\text { Robinia } \\
\text { pseudoacacia }\end{array}$ & Vitis $\times$ ruggerii & $\begin{array}{c}\text { Xanthium } \\
\text { italicum }\end{array}$ \\
\hline \multirow{2}{*}{ Aquatic vegetation } & $\%$ Freq. & 0 & 0 & $7.7^{*}$ & 0 & 0 & $61.5 * * *$ & 0 & 0 & 0 & 0 & 0 \\
\hline & \%C.I. & $0-23.1$ & $0-30.8$ & $15.4-84.6$ & $0-38.5$ & $0-23.1$ & $0-23.1$ & $0-15.4$ & $0-7.7$ & $0-23.1$ & $0-7.7$ & $0-38.5$ \\
\hline \multirow{2}{*}{ Marsh vegetation } & $\%$ Freq. & 6.4 & 4.2 & 48.9 & 17 & 6.4 & 2.1 & 0 & 0 & $0^{*}$ & 0 & $27.7 *$ \\
\hline & \%C.I. & $0-10.6$ & $2.1-17$ & $34-66$ & $8.5-25.5$ & $2.1-12.8$ & $2.1-12.8$ & $0-10.6$ & $0-4.2$ & $2.1-12.8$ & $0-4.2$ & $8.5-25.5$ \\
\hline \multirow[b]{2}{*}{ Lake shore herbaceous vegetation } & \%Freq. & $42.9 * *$ & 0 & 100 & $100 * * *$ & $85.7 * * *$ & 0 & 0 & 0 & 0 & 14.3 & $85.7 * * *$ \\
\hline & $\%$ C.I. & $0-28.6$ & $0-42.9$ & $0-100$ & $0-42.9$ & $0-28.6$ & $0-28.6$ & $0-28.6$ & $0-14.3$ & $0-28.6$ & $0-14.3$ & $0-42.9$ \\
\hline \multirow{2}{*}{$\begin{array}{l}\text { Willow shrublands and } \\
\text { woodlands }\end{array}$} & \%Freq. & 0 & 10 & 70 & $50 *$ & 0 & 0 & 0 & 0 & 0 & 0 & 10 \\
\hline & \%C.I. & $0-20$ & $0-30$ & $10-90$ & $0-40$ & $0-30$ & $0-30$ & $0-20$ & $0-10$ & $0-30$ & $0-10$ & $0-40$ \\
\hline \multirow{2}{*}{$\begin{array}{l}\text { Meso-hygrophilous shrublands } \\
\text { and forests }\end{array}$} & \%Freq. & 0 & 12.5 & 40.6 & $0 * *$ & 0 & 0 & $15.6^{* *}$ & 6.2 & 0 & 3.1 & $0 * *$ \\
\hline & \%C.I. & $0-12.5$ & $0-18.7$ & $28.1-68.7$ & $6.2-28.1$ & $0-15.6$ & $0-15.6$ & $0-12.5$ & $0-6.2$ & $0-15.6$ & $0-6.2$ & $6.2-28.1$ \\
\hline \multirow{2}{*}{ Nitrophilous forests } & \%Freq. & 0 & 0 & 44.4 & 0 & 0 & 0 & 11.1 & 0 & $100 * * *$ & 0 & 0 \\
\hline & $\%$ C.I. & $0-22.2$ & $0-33.3$ & $11.1-88.8$ & $0-44.4$ & $0-22.2$ & $0-22.2$ & $0-22.2$ & $0-11.1$ & $0-22.2$ & $0-11.1$ & $0-44.4$ \\
\hline \multirow{2}{*}{ Plantations } & \%Freq. & 20 & $100^{* * * *}$ & 100 & 0 & 0 & 0 & 0 & 0 & 0 & 0 & 0 \\
\hline & \%C.I. & $0-40$ & $0-40$ & $0-100$ & $0-60$ & $0-40$ & $0-40$ & $0-20$ & $0-20$ & $0-40$ & $0-20$ & $0-60$ \\
\hline
\end{tabular}

Table 3. For each habitat type, the observed mean abundance (expressed as \% cover of the plot) of the IAS are shown with the $95 \%$ confidence intervals (C.I.) obtained from 9999 Monte Carlo simulations. In bold and with asterisks, the IAS mean abundance is significantly different than expected $\left.{ }^{* * *} p<0.001 ;{ }^{* *} p<0.01 ;{ }^{*} p<0.05\right)$.

\begin{tabular}{|c|c|c|c|c|c|c|c|c|c|c|c|c|}
\hline Habitat Type & & $\begin{array}{c}\text { Ambrosia } \\
\text { artemisiifolia }\end{array}$ & $\begin{array}{l}\text { Amorpha } \\
\text { fruticosa }\end{array}$ & $\begin{array}{l}\text { Bidens } \\
\text { frondosa }\end{array}$ & $\begin{array}{c}\text { Bidens } \\
\text { vulgata }\end{array}$ & $\begin{array}{c}\text { Cuscuta } \\
\text { campestris }\end{array}$ & $\begin{array}{c}\text { Elodea } \\
\text { nuttallii }\end{array}$ & Oxalis stricta & $\begin{array}{c}\text { Parthenocissus } \\
\text { quinquefolia }\end{array}$ & $\begin{array}{c}\text { Robinia } \\
\text { pseudoacacia }\end{array}$ & Vitis $\times$ ruggerii & $\begin{array}{c}\text { Xanthium } \\
\text { italicum }\end{array}$ \\
\hline Aquatic vegetation & $\begin{array}{l}\text { \%Abund. } \\
\text { \%C.I. }\end{array}$ & $\begin{array}{c}0 \\
0-12.8\end{array}$ & $\begin{array}{c}0 \\
0-13.1\end{array}$ & $\begin{array}{c}\mathbf{0 . 1} \\
1.3-15.8\end{array}$ & $\begin{array}{c}0 \\
0-4.9\end{array}$ & $\begin{array}{c}0 \\
0-2.7\end{array}$ & $\begin{array}{c}24.2 * * * \\
0-12.1\end{array}$ & $\begin{array}{c}0 \\
0-1.9\end{array}$ & $\begin{array}{c}0 \\
0-0.5\end{array}$ & $\begin{array}{c}0 \\
0-23.1\end{array}$ & $\begin{array}{c}0 \\
0-0.8\end{array}$ & $\begin{array}{c}0 \\
0-10.9\end{array}$ \\
\hline Marsh vegetation & $\begin{array}{c}\text { \%Abund. } \\
\text { \%C.I. }\end{array}$ & $\begin{array}{c}3.3 \\
0-6.1\end{array}$ & $\begin{array}{c}0.6 \\
0.3-6.3\end{array}$ & $\begin{array}{c}6.7 \\
3.7-10\end{array}$ & $\begin{array}{c}0.6 \\
0.4-2.7\end{array}$ & $\begin{array}{c}0.3 \\
0.1-1.4\end{array}$ & $\begin{array}{c}1.8 \\
0.4-6.6\end{array}$ & $\begin{array}{c}0 \\
0-0.8\end{array}$ & $\begin{array}{c}0 \\
0-0.1\end{array}$ & $\begin{array}{c}\mathbf{0}^{* * *} \\
2.1-12.8\end{array}$ & $\begin{array}{c}0 \\
0-0.2\end{array}$ & $\begin{array}{c}7.4^{* * *} \\
1.4-6.7\end{array}$ \\
\hline Lake shore herbaceous vegetation & $\begin{array}{l}\text { \%Abund. } \\
\text { \%C.I. }\end{array}$ & $\begin{array}{c}27^{* *} \\
0-14.3 \\
\end{array}$ & $\begin{array}{c}0 \\
0-16\end{array}$ & $\begin{array}{c}43^{* * * *} \\
0.3-20.1 \\
\end{array}$ & $\begin{array}{c}20 \text { *** } \\
0-7\end{array}$ & $\begin{array}{c}10 * * * \\
0-3.9 \\
\end{array}$ & $\begin{array}{c}0 \\
0-14.4 \\
\end{array}$ & $\begin{array}{c}0 \\
0-3.4 \\
\end{array}$ & $\begin{array}{c}0 \\
0-0.9 \\
\end{array}$ & $\begin{array}{c}0 \\
0-28.6 \\
\end{array}$ & $\begin{array}{c}1.4 \\
0-1.4 \\
\end{array}$ & $\begin{array}{c}23 * * \\
0-14.9 \\
\end{array}$ \\
\hline $\begin{array}{l}\text { Willow shrublands and } \\
\text { woodlands }\end{array}$ & $\begin{array}{l}\text { \%Abund. } \\
\text { \%C.I. }\end{array}$ & $\begin{array}{c}0 \\
0-15.3\end{array}$ & $\begin{array}{c}3.7 \\
0-13\end{array}$ & $\begin{array}{c}8 \\
0.7-16.5\end{array}$ & $\begin{array}{c}2 \\
0-5.6\end{array}$ & $\begin{array}{c}0 \\
0-2.7\end{array}$ & $\begin{array}{c}0 \\
0-14\end{array}$ & $\begin{array}{c}0 \\
0-2.5\end{array}$ & $\begin{array}{c}0 \\
0-0.6\end{array}$ & $\begin{array}{c}0 \\
0-30\end{array}$ & $\begin{array}{c}0 \\
0-1\end{array}$ & $\begin{array}{c}0.1 \\
0-12.5\end{array}$ \\
\hline $\begin{array}{l}\text { Meso-hygrophilous shrublands } \\
\text { and forests }\end{array}$ & $\begin{array}{l}\text { \%Abund. } \\
\text { \%C.I. }\end{array}$ & $\begin{array}{c}0 \\
0-7.6 \\
\end{array}$ & $\begin{array}{c}0.4 \\
0-7.8 \\
\end{array}$ & $\begin{array}{c}1.5^{* *} \\
2.6-10.9 \\
\end{array}$ & $\begin{array}{c}\mathbf{0}^{* *} \\
0.2-3.2 \\
\end{array}$ & $\begin{array}{c}0 \\
0-1.8 \\
\end{array}$ & $\begin{array}{c}0 \\
0-7.8 \\
\end{array}$ & $\begin{array}{c}0.6 \\
0-1.2 \\
\end{array}$ & $\begin{array}{c}0.2 \\
0-0.2 \\
\end{array}$ & $\begin{array}{c}0 \\
0-15.6 \\
0\end{array}$ & $\begin{array}{c}0.1 \\
0-0.4 \\
\end{array}$ & $\begin{array}{c}\mathbf{0}^{* * * *} \\
0.8-7.9 \\
\end{array}$ \\
\hline Nitrophilous forests & $\begin{array}{l}\text { \%Abund. } \\
\text { \%C.I. }\end{array}$ & $\begin{array}{c}0 \\
0-15.8\end{array}$ & $\begin{array}{c}0 \\
0-17.5\end{array}$ & $\begin{array}{c}1.3 \\
0.7-17.8\end{array}$ & $\begin{array}{c}0 \\
0-6.6\end{array}$ & $\begin{array}{c}0 \\
0-2.9\end{array}$ & $\begin{array}{c}0 \\
0-15.6\end{array}$ & $\begin{array}{c}2.7 \\
0-2.7\end{array}$ & $\begin{array}{c}0 \\
0-0.7\end{array}$ & $\begin{array}{l}100 * * * * \\
0-22.2\end{array}$ & $\begin{array}{c}0 \\
0-1.1\end{array}$ & $\begin{array}{c}0 \\
0-13.7\end{array}$ \\
\hline Plantations & $\begin{array}{l}\text { \%Abund. } \\
\text { \%C.I. }\end{array}$ & $\begin{array}{c}0.4 \\
0-20\end{array}$ & $\begin{array}{c}64 * * * \\
0-18\end{array}$ & $\begin{array}{c}10.6 \\
0-24.4\end{array}$ & $\begin{array}{c}0 \\
0-8\end{array}$ & $\begin{array}{c}0 \\
0-5.2\end{array}$ & $\begin{array}{c}0 \\
0-18\end{array}$ & $\begin{array}{c}0 \\
0-4.8\end{array}$ & $\begin{array}{c}0 \\
0-1.2\end{array}$ & $\begin{array}{c}0 \\
0-40\end{array}$ & $\begin{array}{c}0 \\
0-2\end{array}$ & $\begin{array}{c}0 \\
0-17.2\end{array}$ \\
\hline
\end{tabular}


The number of occurrences (Table 2) was higher than expected from a random null model for E. nuttallii in aquatic vegetation, $X$. italicum in marsh vegetation, $A$. artemisiifolia, $B$. vulgata, C. campestris and $X$. italicum in lake shore herbaceous vegetation, $B$. vulgata in willow shrublands and woodlands, O. stricta in meso-hygrophilous shrublands and forests, R. pseudoacacia in nitrophilous forests and A. fruticosa in plantations, while the frequencies were lower than expected from a random null model for B. frondosa in aquatic vegetation, R. pseudoacacia in marsh vegetation and B. vulgata and X. italicum in meso-hygrophilous shrublands and forests.

Where frequencies were significantly higher (or lower) than null models, the cover of IAS within the plots followed the same trend (Table 3), or, rather, IAS that had higher frequencies also had higher abundances and vice versa, except for $B$. frondos $a$ in lake shore herbaceous vegetation, where its frequency was not significant but its abundance was higher than random, B. vulgata in willow shrublands and woodlands where its frequency was significantly higher but its abundance was not, B. frondosa and O. stricta in meso-hygrophilous shrublands and forests habitats, where the former had a significantly lower abundance and the latter had a significantly higher frequency. The species that did not differ by the random expectation, both in terms of frequencies and abundances, were P. quinquefolia and $V$. $\times$ ruggerii. Overall, considering the results provided by Tables 2 and 3 , there were 11 preferences and five avoidances for habitats by IAS.

The results of IAS richness per habitat analysis (Table 4) show that the observed IAS richness in aquatic vegetation, marsh vegetation and meso-hygrophilous shrublands and forests was significantly lower than random richness resulting from the null models.

Table 4. For each habitat type the observed IAS richness values are shown with the $95 \%$ confidence intervals of the random IAS richness and the $p$-values (two-tailed test) obtained by reshuffling the matrix assembled with the random frequencies of each IAS per habitat 9999 times (keeping the IAS probability resulting from the first null model simulations fixed). In bold, the $p$-values are significantly lower than expected.

\begin{tabular}{cccc}
\hline Habitat Type & Observed IAS Richness & Random IAS Richness C. I. & $p$-Value \\
\hline Aquatic vegetation & 2 & $4-9$ & $\mathbf{0 . 0 0 0 8}$ \\
Marsh vegetation & 7 & $9-11$ & $\mathbf{0 . 0 0 0 8}$ \\
Lake shore herbaceous vegetation & 6 & $2-8$ & 0.3482 \\
Willow shrublands and woodlands & 4 & $3-9$ & 0.1438 \\
Meso-hygrophilous shrublands and forests & 5 & $7-11$ & $\mathbf{0 . 0 0 0 4}$ \\
Nitrophilous forests & 3 & $3-8$ & 0.0611 \\
Plantations & 3 & $1-7$ & 0.3837 \\
\hline
\end{tabular}

\section{Discussion}

In this study, we used a null model simulation to test the association between alien species and different habitats in a wetland PA, taking into account only the habitat as a possible determinant for the observed resulting distribution. A first analysis of the alien floristic data shows that a third of the sampled IAS belongs to the Asteraceae family, confirming it as a successful invader taxon [85-88], among which, in particular, Bidens frondosa invaded indistinctly almost every habitat in the study area, except for the aquatic vegetation. Moreover, our results pointed out that IAS frequency, abundance and richness were not randomly distributed within habitats and that some types of habitat were more prone to invasion by IAS (see Tables 2-4).

The differences we observed in IAS distribution across habitats might be indirectly inferred by considering both habitat features and IAS functional traits and referring to IAS autoecology described in other studies $[13,19,41,89]$. Analyzing one habitat at a time and both the IAS frequencies and abundances that were significantly higher (or lower) than expected by chance, starting from the aquatic vegetation, we observed that the only successful invader here was Elodea nuttallii, a perennial submerged rooted hydrophyte native to North America. This species was detected for the first time in Lake Doberdò in 2011 [90] and seems to have completely replaced another IAS, Elodea canadensis, 
which was previously reported in the area [91]. E. nuttallii asexual propagation is reported to be improved by nutrient rich sediments [92] and its regeneration and colonization abilities are slightly higher than E. canadensis, but these characteristics alone seem insufficient to explain the displacement of E. canadensis by E. nuttallii in the area [93]. However, the replacement of E. canadensis by E. nuttallii has been observed in many European areas [94-96]. Conversely, B. frondosa occurrence and abundance in this habitat was significantly lower than random expectation, a feature easily explainable taking in account that the species cannot live submerged for long periods. In this case, it was pretty obvious that the only successful IAS would have been a plant adapted to live in the water, but, although trivial, this result served to verify the null model efficiency.

In the marsh vegetation, the observed occurrence and abundance of Xanthium italicum was higher than expected, while the occurrence and abundance of Robinia pseudoacacia was lower than random expectation. X. italicum was mostly found in those communities occupying the dryer parts of the marsh vegetation, particularly in the areas where nutrients accumulate [97]. For Lake Doberdò, these situations occur in the marginal areas of the lake, which dry out during the summer and are subject to the deposition of nutrients due to the direction of the flowing water. X. italicum fruits are easily dispersed by clinging to the fur of animals and its seeds can tolerate prolonged submersion without showing significant effects on final germination during the dry season [98], and, for these reasons, it is particularly competitive in this environment. Concerning the distribution of $R$. pseudoacacia in marsh vegetation, its lower observed occurrence and abundance is related to the species avoidance strategy to protracted submersion [99], a characteristic in common with most of trees with the exception for those adapted to wet conditions (e.g., Salix spp.).

The lake shore herbaceous vegetation is distinctly the most invaded habitat as shown both in terms of IAS significant occurrences and abundances (Tables 2 and 3). Indeed, this habitat type showed highly significant frequencies for four species (Ambrosia artemisiifolia, Bidens vulgata, Cuscuta campestris and X. italicum) and highly significant abundances for all the previous ones plus B. frondosa. Its high indiscriminate invasibility is probably related to three characteristics of the habitat, namely recurrent disturbs linked to the peculiar hydrological regime (water level oscillations, duration and seasonality of floods), the high availability of nutrients transported by water flow especially in spring period [100] and high solar energy availability. These characteristics are also confirmed by the observed poorly structured herbaceous native communities, which showed high dynamism in their structure during the year, shifting from the predominance of associations of the Agrostietea stoloniferae class in spring to that of associations of the Bidentetea tripartitae class in the late summer, which leads to an environment more susceptible to invasion [29]. We could detect the invasion success of $A$. artemisiifolia, an annual plant native to North America, as related to both high solar radiation (due to the available spaces in these plant communities) and the nutrients level in the habitat [101]. B. vulgata and B. frondosa were facilitated by the high dynamism in the resident plant communities, in which the native $B$. tripartita was replaced by both $B$. vulgat $a$ and $B$. frondosa. The latter is known to be more competitive than its native congener for many characteristics, such as a higher competitiveness where the nutrients level is high, a high plasticity of the vegetative phase length that allows it to grow taller than B. tripartita and to foster seed production and, finally, cause the greater resistance to drought during summer [102-104]. Similar characteristics are probably also present in $B$. vulgata, which is often reported in co-occurrence with $B$. frondosa $[105,106]$. Furthermore, Bidens seeds are easily dispersed by animals and humans for tens of $\mathrm{km}$, explaining their wide distribution in the study area. For the last two species, X. italicum and C. campestris, which are strongly related because the latter grows often as parasite on the former, they have been found as strongly associated to the lake shore herbaceous vegetation, both IAS finding a suitable habitat because the first is a nitrophilous species, as stated before, and the second normally grows as a parasite by twisting around the stems of species of Polygonum, Xanthium and several other psammophilous plants [107].

As regards the willow shrublands and woodlands habitat, we observed an occurrence higher than expected for $B$. vulgata but its abundance was not significantly different than random. Its frequency 
suggests a certain degree of affinity for this habitat, due to nutrients accumulation, although lower than in the lake shore herbaceous vegetation. However, the not significant abundance could indicate the presence of limiting factors, for example, a lower light availability due to higher shading.

In the meso-hygrophilous shrublands and forests habitat, both the frequency and abundance of $B$. vulgata and X. italicum were lower than expected, while only the abundance of $B$. frondosa was significantly lower than random expectation. Conversely, Oxalis stricta occurrence was, here, significantly higher. O. stricta is a perennial herbaceous plant with overwintering buds at ground level, native to North America. It prefers moist soils, both in sunny and partially shaded areas [108]. Its occurrence here was favored for two reasons: the low or absent competition with the sparse herbaceous vegetation [30] and the high coverage of native shrubs that precludes potential invasions by other IAS. This is confirmed by the low frequencies and abundances of the other IAS. The habitat resistance to invasion is also favored by the slope that let water wash away nutrients from the soil after the lake floods.

R. pseudoacacia was highly associated with the nitrophilous forests habitat where it is known to add or replace the native Sambucus nigra [109], showing high cover values also due to asexual reproduction through root suckering. Here, other IAS were limited in their spreading (see Tables 2 and 3 ) due to shading conditions and to competition with highly abundant $R$. pseudoacacia.

For what concerned the poplar plantations, we observed the significant occurrence and abundance of Amorpha fruticosa, a woody shrub native to North America. A. fruticosa can tolerate dry soils, but it is most abundant along river or lake banks and at the edges of flooded forests. The plant grows well in medium to wet, well-drained soils in full sun to light shade and is tolerant of occasional flooding, lasting less than 30 days [110-114]. This explains its observed high frequency in the habitat, which is more favorable to the species because of the moist soil, the light shade and the occasional flooding events. Its high potential invasive behavior is due not only to its high tolerance of various environmental conditions but also to its reproduction strategies through self-seeding and suckers to form thickets [110]. A. fruticosa usually colonizes degraded wet habitats but also invades natural plant communities where it competes with native vegetation leading to a decrease in species diversity [115]. For this reason, it represents a serious threat for the diversity conservation, especially in wetlands.

Comparing observed and simulated IAS richness (Table 4) we can highlight that some habitats were less prone to a non-selective IAS invasion than others. While this may be quite obvious for aquatic vegetation, where only one of the sampled IAS was a hydrophyte, this is quite surprising for marsh vegetation and meso-hygrophilous shrublands and forests habitats. Although both habitats presented a relatively high number of sampled IAS, 7 and 5, respectively, they represented together the $77 \%$ of the study area, and, for the species richness-area relation [116], we could have expected to spot a higher IAS richness. These habitats were less prone to invasion, in case of the marsh vegetation because of extreme conditions caused by periodical and long-lasting floods that require special adaptions for plants to survive, and in that of meso-hygrophilous shrublands and forests because of a medium-low nutrients level and low light availability, which do not favor the spread of IAS, which are generally nutrient/light-demanding species.

In general, what we observed in the study area was that invasion was promoted in the habitats where one or more of the following conditions were satisfied: an intermediate disturbance level, caused by the water fluctuation or by the high dynamism of the communities within a habitat, a high level of nutrients and a medium to high light availability. These factors favored IAS invasion as they are known to be more competitive than natives both in a condition of intermediate disturbance [117] and when resources are easily available $[30,41,89,118]$. On the contrary, invasion by terrestrial IAS was avoided in the habitats where the communities presented a stable structure during the year, without seasonal changes, a medium nutrients level, moderate to low light availability or extreme conditions caused by long-lasting floods. Such different conditions in the small Lake Doberdò area were reflected as well by the native communities, represented by 33 different associations adapted to those peculiar environments. However, the high resource availability and the advantageous biotic 
interaction observed for some habitats may become a key driver along the subsequent stages of the invasion, leading to a loss in native diversity $[19,41,89,119]$. This is even more serious considering that the habitats are part of a wetland PA, in a global scenario of a dramatic decline in wetland areas due to extensive habitat degradation and fragmentation driven by human activities [56-58]. An early warning and eradication of IAS may impede new invasions and/or halt the ongoing ones: this would be particularly urgent in wetland PAs if we want to preserve their biodiversity, their conservation purpose and prevent the degeneration of native communities.

Regarding the possible weakness of the null model simulations, in some cases they were not capable of highlighting the actual distribution pattern of species; e.g., E. nuttallii is a hydrophyte and its distribution across the non-aquatic habitats was never significantly lower than random, as was expected. In particular, IAS avoidances may have been masked by confidence intervals in some cases (see Tables 2 and 3) as the confidence intervals have almost always the lower limit equal to 0 . This probably happened because the random reassemble of the matrix was only weighted by the habitat area. Moreover, the null model suffered also for the low frequencies of certain species (e.g., P. quinquefolia and $V$. $\times$ ruggerii) even though, overall, it provided useful results. In fact, we were not completely focused on highlighting the actual distribution of all IAS within the wetland, but rather on pointing out those IAS that were particularly threatening for the different habitats of the PA.

We also have to stress that the adopted sampling design was originally planned to evaluate the occurrence of alien species in different habitats in a rather complex area and to assess the conservation status of the native communities. A multi-scale approach should have been adopted considering that the pattern of variation in the alien/native species are strongly scale dependent [19]. The adopted plot size, then, somehow questionable for the characterization of plant community structure, can represent a limitation of this study and future analyses will take in account a multi-scale approach.

Nonetheless, the method tested in this study provides useful information to monitor and manage the IAS threat within PAs. By inferring important ecological property leading to habitat invasion without sampling the environmental characteristics of the habitats (an expensive and time-consuming operation in the field), we suggest using the applied method as a complementary tool in the analysis of biological invasions.

\section{Conclusions}

The results highlight an interesting linkage between IAS and invaded habitats, confirming that some habitats are more prone to biological invasion than others, and that environmental conditions can promote or avoid invasion depending also on the specific IAS ecology and biology. The study clearly shows the role of habitats in filtering the invasion depending on the species, besides the role of natural intermediate disturbance resulting on one side in an environment rich in biodiversity and on the other side advantaging the IAS colonization of the area [117].

Concerning the method, it enabled us to derive useful information, proving to be a low-cost analysis to routinely integrate PAs' management activities. In particular, it may help to detect highly endangered habitats and to invest time and money more efficiently to control IAS, and, when possible, also to prevent IAS colonization.

Supplementary Materials: The following are available online at http://www.mdpi.com/1424-2818/12/7/267/s1, Figure S1: Habitat map based on vegetation types of the study area (Lake Doberdò).

Author Contributions: Conceptualization and methodology all authors; description and attribution of plant communities M.C., L.P.; data collection F.L., M.C., A.A.; formal analysis and data curation F.L., M.C., E.T.; writing of the manuscript F.L., M.C., A.A., E.T., M.S., G.B.; supervision G.B. All authors have read and agreed to the published version of the manuscript.

Funding: This research received no external funding.

Acknowledgments: We thank three anonymous reviewers for providing valuable advices to improve the article.

Conflicts of Interest: The authors declare no conflict of interest. 


\section{Abbreviations}

IAS Invasive Alien Species

PA Protected Area

\section{References}

1. Millennium Ecosystem Assessment. Ecosystems and Human Well-Being: Biodiversity Synthesis; World Resources Institute: Washington, DC, USA, 2005.

2. Simberloff, D.; Martin, J.L.; Genovesi, P.; Maris, V.; Wardle, D.A.; Aronson, J.; Courchamp, F.; Galil, B.; García-Berthou, E.; Pascal, M.; et al. Impacts of biological invasions: What's what and the way forward. Trends Ecol. Evol. 2013, 28, 58-66. [CrossRef] [PubMed]

3. Courchamp, F.; Fournier, A.; Bellard, C.; Bertelsmeier, C.; Bonnaud, E.; Jeschke, J.M.; Russell, J.C. Invasion Biology: Specific Problems and Possible Solutions. Trends Ecol. Evol. 2017, 32, 13-22. [CrossRef] [PubMed]

4. Vitousek, P.M.; D’Antonio, C.M.; Loope, L.L.; Rejmánek, M.; Westbrooks, R. Introduced species: A significant component of human-caused global change. New Zealand J. Ecol. 1997, 21, 1-16.

5. Pyšek, P. Alien and native species in central European urban floras: A quantitative comparison. J. Biogeogr. 1998, 25, 155-163. [CrossRef]

6. Ricotta, C.; Godefroid, S.; Rocchini, D. Patterns of native and exotic species richness in the urban flora of Brussels: Rejecting the 'rich get richer' model. Biol. Invasions 2010, 12, 233-240. [CrossRef]

7. Aerts, R.; Ewald, M.; Nicolas, M.; Piat, J.; Skowronek, S.; Lenoir, J.; Hattab, T.; Garzon-Lopez, C.X.; Feilhauer, H.; Schmidtlein, S.; et al. Invasion by the alien tree Prunus serotina alters ecosystem functions in a temperate deciduous forest. Front. Plant Sci. 2017, 8, 1-11. [CrossRef]

8. Hattab, T.; Garzon-Lopez, C.X.; Ewald, M.; Skowronek, S.; Aerts, R.; Horen, H.; Brasseur, B.; Gallet-Moron, E.; Spicher, F.; Decocq, G.; et al. A unified framework to model the potential and realized distributions of invasive species within the invaded range. Divers. Distrib. 2017, 23, 806-819. [CrossRef]

9. Ceschin, S.; Ellwood, N.T.W.; Ferrante, G.; Mariani, F.; Traversetti, L. Habitat change and alteration of plant and invertebrate communities in waterbodies dominated by the invasive alien macrophyte Lemna minuta Kunth. Biol. Invasions 2020, 22, 1325-1337. [CrossRef]

10. Blackburn, T.M.; Pyšek, P.; Bacher, S.; Carlton, J.T.; Duncan, R.P.; Jarošík, V.; Wilson, J.R.U.; Richardson, D.M. A proposed unified framework for biological invasions. Trends Ecol. Evol. 2011, 26, 333-339. [CrossRef] [PubMed]

11. Hulme, P.E.; Pyšek, P.; Jarošík, V.; Pergl, J.; Schaffner, U.; Vilà, M. Bias and error in understanding plant invasion impacts. Trends Ecol. Evol. 2013, 28, 212-218. [CrossRef]

12. Davis, M.A.; Thompson, K.; Philip Grime, J. Invasibility: The local mechanism driving community assembly and species diversity. Ecography 2005, 28, 696-704. [CrossRef]

13. Siniscalco, C.; Barni, E.; Bacaro, G. Non-native species distribution along the elevation gradient in the western Italian Alps. Plant Biosyst. 2011, 145, 150-158. [CrossRef]

14. Barni, E.; Bacaro, G.; Falzoi, S.; Spanna, F.; Siniscalco, C. Establishing climatic constrains shaping the distribution of alien plant species along the elevation gradient in the Alps. Plant Ecol. 2012, 213, 757-767. [CrossRef]

15. Jeschke, J.M. General hypotheses in invasion ecology. Divers. Distrib. 2014, 20, 1229-1234. [CrossRef]

16. Bacaro, G.; Maccherini, S.; Chiarucci, A.; Jentsch, A.; Rocchini, D.; Torri, D.; Gioria, M.; Tordoni, E.; Martellos, S.; Altobelli, A.; et al. Distributional patterns of endemic, native and alien species along a roadside elevation gradient in Tenerife, Canary Island. Commun. Ecol. 2015, 16, 223-234. [CrossRef]

17. Ricciardi, A.; Blackburn, T.M.; Carlton, J.T.; Dick, J.T.A.; Hulme, P.E.; Iacarella, J.C.; Jeschke, J.M.; Liebhold, A.M.; Lockwood, J.L.; MacIsaac, H.J.; et al. Invasion Science: A Horizon Scan of Emerging Challenges and Opportunities. Trends Ecol. Evol. 2017, 32, 464-474. [CrossRef]

18. Tordoni, E.; Napolitano, R.; Nimis, P.; Castello, M.; Altobelli, A.; Da Re, D.; Zago, S.; Chines, A.; Martellos, S.; Maccherini, S.; et al. Diversity patterns of alien and native plant species in Trieste port area: Exploring the role of urban habitats in biodiversity conservation. Urban Ecosyst. 2017, 20, 1151-1160. [CrossRef]

19. Landi, S.; Tordoni, E.; Amici, V.; Bacaro, G.; Carboni, M.; Filibeck, G.; Scoppola, A.; Bagella, S. Contrasting patterns of native and non-native plants in a network of protected areas across spatial scales. Biodiv. Conserv. 2020, 29, 2035-2053. [CrossRef] 
20. Simberloff, D. The role of propagule pressure in biological invasions. Ann. Rev. Ecol. Evol. Syst. 2009, 40, 81-102. [CrossRef]

21. Lockwood, J.L.; Cassey, P.; Blackburn, T. The role of propagule pressure in explaining species invasions. Trends Ecol. Evol. 2005, 20, 223-228. [CrossRef]

22. Lonsdale, W.M. Global patterns of plant invasions and the concept of invasibility. Ecology 1999, 80, 1522-1536. [CrossRef]

23. Tilman, D. Niche tradeoffs, neutrality, and community structure: A stochastic theory of resource competition, invasion, and community assembly. Proc. Natl. Acad. Sci. USA 2004, 101, 10854-10861. [CrossRef]

24. Hui, C.; Richardson, D.M.; Landi, P.; Minoarivelo, H.O.; Garnas, J.; Roy, H.E. Defining invasiveness and invasibility in ecological networks. Biol. Invasions 2016, 18, 971-983. [CrossRef]

25. Rejmánek, M. Species richness and resistance to invasions. In Diversity and Processes in Tropical Forest Ecosystems; Orians, G.H., Dirzo, R., Cushman, J.H., Eds.; Springer: Berlin/Heidelberg, Germany, 1996; Volume 122, pp. 153-172.

26. Pyšek, P.; Jarošík, V.; Kučera, T. Patterns of invasion in temperate nature reserves. Biol. Cons. 2002, 104, 13-24. [CrossRef]

27. Pyšek, P.; Sádlo, J.; Mandák, B. Catalogue of alien plants of the Czech Republic. Preslia 2002, 74, 97-186.

28. Rejmánek, M.; Richardson, D.M.; Pyšek, P. Plant Invasions and Invasibility of Plant Communities. In Vegetation Ecology; van der Maarel, E., Franklin, J., Eds.; John Wiley \& Sons, Ltd.: Oxford, UK, 2013; pp. 387-424.

29. Alpert, P.; Bone, E.; Holzapfel, C. Invasiveness, invasibility and the role of environmental stress in the spread of non-native plants. Persp. Plant Ecol. Evol. Syst. 2000, 3, 52-66. [CrossRef]

30. Pyšek, P.; Richardson, D.M. Invasive Plants. In Encyclopedia of Ecology; Jørgensen, S.E., Ed.; Elsevier: Amsterdam, The Netherlands, 2008; Volume 1, pp. 2011-2019.

31. Richardson, D.M.; Pyšek, P.; Carlton, J.T. A Compendium of Essential Concepts and Terminology in Invasion Ecology. In Fifty Years of Invasion Ecology; Richardson, D.M., Ed.; Wiley-Blackwell: Oxford, UK, 2010; pp. 409-420.

32. Moravcová, L.; Pyšek, P.; Jarošík, V.; Pergl, J. Getting the Right Traits: Reproductive and Dispersal Characteristics Predict the Invasiveness of Herbaceous Plant Species. PLoS ONE 2015, 10, e0123634. [CrossRef]

33. Ceschin, S.; Abati, S.; Ellwood, N.T.W.; Zuccarello, V. Riding invasion waves: Spatial and temporal patterns of the invasive Lemna minuta from its arrival to its spread across Europe. Aqu. Bot. 2018, 150, 1-8. [CrossRef]

34. Tecco, P.A.; Díaz, S.; Cabido, M.; Urcelay, C. Functional traits of alien plants across contrasting climatic and land-use regimes: Do aliens join the locals or try harder than them? J. Ecol. 2010, 98, 17-27. [CrossRef]

35. Funk, J.L. The physiology of invasive plants in low-resource environments. Conserv. Physiol. 2013, 1, cot026. [CrossRef]

36. Funk, J.L.; Standish, R.J.; Stock, W.D.; Valladares, F. Plant functional traits of dominant native and invasive species in mediterranean-climate ecosystems. Ecology 2016, 97, 75-83. [CrossRef] [PubMed]

37. Richardson, D.M.; Pyšek, P. Plant invasions: Merging the concepts of species invasiveness and community invasibility. Prog. Phys. Geog. Earth Environ. 2006, 30, 409-431. [CrossRef]

38. Hayes, K.R.; Barry, S.C. Are there any consistent predictors of invasion success? Biol. Invasions 2008, 10, 483-506. [CrossRef]

39. Lembrechts, J.J.; Rossi, E.; Milbau, A.; Nijs, I. Habitat properties and plant traits interact as drivers of non-native plant species' seed production at the local scale. Ecol. Evol. 2018, 8, 4209-4223. [CrossRef]

40. Catford, J.A.; Vesk, P.A.; Richardson, D.M.; Pyšek, P. Quantifying levels of biological invasion: Towards the objective classification of invaded and invasible ecosystems. Glob. Chang. Biol. 2012, 18, 44-62. [CrossRef]

41. Tordoni, E.; Petruzzellis, F.; Nardini, A.; Savi, T.; Bacaro, G. Make it simpler: Alien species decrease functional diversity of coastal plant communities. J. Veg. Sci. 2019, 30, 498-509. [CrossRef]

42. Milbau, A.; Stout, J.C. Factors associated with alien plants transitioning from casual, to naturalized, to invasive. Conserv. Biol. 2008, 22, 308-317. [CrossRef]

43. Jansen, F.; Ewald, J.; Zerbe, S. Ecological preferences of alien plant species in North-Eastern Germany. Biol. Invasions 2011, 13, 2691-2701. [CrossRef]

44. Jauni, M.; Hyvonen, T. Interactions between alien plant species traits and habitat characteristics in agricultural landscapes in Finland. Biol. Invasions 2012, 14, 47-63. [CrossRef] 
45. Simonova, D.; Lososova, Z. Which factors determine plant invasions in man-made habitats in the Czech Republic? Persp. Plant Ecol. Evol. Syst. 2008, 10, 89-100. [CrossRef]

46. Chytry, M.; Pysek, P.; Wild, J.; Pino, J.; Maskell, L.C.; Vilà, M. European map of alien plant invasions based on the quantitative assessment across habitats. Divers. Distrib. 2009, 15, 98-107. [CrossRef]

47. Carboni, M.; Santoro, R.; Acosta, A.T.R. Dealing with scarce data to understand how environmental gradients and propagule pressure shape fine-scale alien distribution patterns on coastal dunes. J. Veg. Sci. 2011, 22, 751-765. [CrossRef]

48. Milbau, A.; Stout, J.C.; Graae, B.J.; Nijs, I. A hierarchical framework for integrating invasibility experiments incorporating different factors and spatial scales. Biol. Invasions 2009, 11, 941-950. [CrossRef]

49. Lembrechts, J.J.; Lenoir, J.; Nuñez, M.A.; Pauchard, A.; Geron, C.; Bussé, G.; Nijs, I. Microclimate variability in alpine ecosystems as stepping stones for non-native plant establishment above their current elevational limit. Ecography 2017, 40, 1-9. [CrossRef]

50. Hulme, P.E. Biological invasions: Winning the science battles but losing the conservation war? Oryx 2003, 37, 178-193. [CrossRef]

51. Chytrý, M.; Jarošík, V.; Pyšek, P.; Hájek, O.; Knollová, I.; Tichý, L.; Danihelka, J. Separating habitat invasibility by alien plants from the actual level of invasion. Ecology 2008, 89, 1541-1553. [CrossRef]

52. Foxcroft, L.C.; Pyšek, P.; Richardson, D.M.; Genovesi, P. Plant Invasions in Protected Areas: Patterns, Problems and Challenges; Springer: Dordrecht, The Netherlands, 2013.

53. Sitzia, T.; Campagnaro, T.; Kowarik, I.; Trentanovi, G. Using forest management to control invasive alien species: Helping implement the new European regulation on invasive alien species. Biol. Invasions 2016, 18, 1-7. [CrossRef]

54. Bazzichetto, M.; Malavasi, M.; Bartak, V.; Acosta, A.T.R.; Rocchini, D.; Carranza, M.L. Plant invasion risk: A quest for invasive species distribution modelling in managing protected areas. Ecol. Indic. 2018, 95, 311-319. [CrossRef]

55. Houlahan, J.E.; Findlay, C.S. Effect of Invasive Plant Species on Temperate Wetland Plant Diversity. Conserv. Biol. 2004, 18, 1132-1138. [CrossRef]

56. Jones, T.A.; Hughes, J.M.R. Wetland inventories and wetland loss studies: A European perspective. In Waterfowl and Wetland Conservation in the 1990s: A Global Perspective; Moser, M., Prentice, R.C., van Vessem, J., Eds.; IWRB Spec. Publ. No. 26; Proc IWRB Symp: St Petersburg Beach, FL, USA; Slimbridge, UK, 1993; pp. 164-169.

57. European Commission. Life and Europe's Wetlands. Restoring a Vital Ecosystem; European Commission: Luxembourg, 2007.

58. Jantke, K.; Schleupner, C.; Schneider, U.A. Gap analysis of European wetland species: Priority regions for expanding the Natura 2000 network. Biodivers. Conserv. 2011, 20, 581-605. [CrossRef]

59. Abellán, P.; Sanchez-Fernandez, D.; Velasco, J.; Millan, A. Effectiveness of protected area networks in representing freshwater biodiversity: The case of a Mediterranean river basin (south-eastern Spain). Aquat. Conserv. 2007, 17, 361-374. [CrossRef]

60. Roe, J.; Georges, A. Heterogeneous wetland complexes, buffer zones, and travel corridors: Landscape management for freshwater reptiles. Biol. Conserv. 2007, 135, 67-76. [CrossRef]

61. Zedler, J.B.; Kercher, S. Causes and consequences of invasive plants in wetlands: Opportunities, opportunists, and outcomes. Crit. Rev. Plant. Sci. 2004, 23, 431-452. [CrossRef]

62. Berg, J.A.; Meyer, G.A.; Young, E.B. Propagule pressure and environmental conditions interact to determine establishment success of an invasive plant species, glossy buckthorn (Frangula alnus), across five different wetland habitat types. Biol. Invasions 2016, 18, 1363-1373. [CrossRef]

63. Cancian, G. Il Carso Monfalconese: Litostratigrafia, Tettonica, Speleomorfologia e Speleogenesi; Grotte d'Italia: Bologna, Italy, 1976; Volume 5, pp. 5-30.

64. Cucchi, F.; Pugliese, N.; Ulcigrai, F. Il Carso Triestino: Note geologiche e stratigrafiche. Int. J. Speleol. 1989, 18, 49-64. [CrossRef]

65. Samez, D.; Casagrande, G.; Cucchi, F.; Zini, L. Idrodinamica dei laghi di Doberdò e di Pietrarossa (Carso Classico, Italia): Relazioni con le piene dei fiumi Isonzo, Vipacco e Timavo. Atti Mem. Commun. Grotte E. Boegan 2005, 40, 133-152. 
66. Cremaschi, M. The loess in northern and central Italy: A loess basin between the Alps and the Mediterranean regions. In The Loess in Northern and Central Italy; Cremaschi, M., Ed.; Centro di studio per la Stratigrafia e Petrografia delle Alpi Centrali, Editrice Gutenberg: Milano, Italy, 1990; pp. 15-19.

67. Cucchi, F.; Forti, P.; Marinetti, E.; Zini, L. Recent developments in knowledge of the hydrogeology of the classical karst. Acta Carsologica 2000, 29, 55-78.

68. Zini, L.; Calligaris, C.; Zavagno, E. Classical Karst hydrodynamics: A shared aquifer within Italy and Slovenia. Evolving Water Resources Systems: Understanding, Predicting and Managing Water-Society Interactions. In Proceedings of the ICWRS2014, Bologna, Italy, 4-6 June 2014; IAHS Publ. 364. pp. 499-504.

69. Calligaris, C.; Mezga, K.; Slejko, F.F.; Zini, L. Groundwater Characterization by Means of Conservative $(\delta 18 \mathrm{O}$ and $\delta 2 \mathrm{H})$ and Non-Conservative $(87 \mathrm{Sr} / 86 \mathrm{Sr})$ Isotopic Values: The Classical Karst Region Aquifer Case (Italy-Slovenia). Geosciences 2018, 8, 321. [CrossRef]

70. Cucchi, F.; Furlani, S.; Marinetti, E. Monitoraggio in continuo del livello del lago di Doberdò. Atti Mem. Commun. Grotte E. Boegan 1999, 37, 143-153.

71. Devillers, P.; Devillers-Terschuren, J.; Ledant, J.P. CORINE Biotopes Manual. Habitats of the European Community. Data Specifications_-Part 2; EUR 12587/3 EN; Office for Official Publications of the European Communities: Luxembourg, 1991.

72. Devillers, P.; Devillers-Terschuren, J. A Classification of Palaearctic Habitats; Nature and environment, No 78; Council of Europe: Strasbourg, France, 1996.

73. Davies, C.E.; Moss, D.; Hill, M.O. EUNIS Habitat Classification Revised 2004; Report to the European Topic Centre on Nature Protection and Biodiversity; European Environment Agency: Copenhagen, Denmark, 2004.

74. European Commission. Interpretation Manual of European Union Habitats; EUR 28, April 2013, DG Environment, Nature ENV B.3; European Commission: Luxembourg, 2013; p. 144.

75. Braun-Blanquet, J. Pflanzensoziologie, 3rd ed.; Springer: Vienna, Austria, 1964.

76. Westhoff, V.; Van der Maarel, E. The Braun-Blanquet approach. In Classification of Plant Communities, 2nd ed.; Whittaker, R.H., Ed.; Junk: The Hague, The Netherlands, 1978.

77. Biondi, E. Phytosociology today: Methodological and conceptual evolution. Plant Biosyst. 2011, 145, 19-29. [CrossRef]

78. Galasso, G.; Conti, F.; Peruzzi, L.; Ardenghi, N.M.G.; Banfi, E.; Celesti-Grapow, L.; Albano, A.; Alessandrini, A.; Bacchetta, G.; Ballelli, S.; et al. An updated checklist of the vascular flora alien to Italy. Plant Biosyst. 2018, 152, 556-592. [CrossRef]

79. Biondi, E.; Blasi, C.; Allegrezza, M.; Anzellotti, I.; Azzella, M.M.; Carli, E.; Casavecchia, S.; Copiz, R.; Del Vico, E.; Facioni, L.; et al. Plant communities of Italy: The Vegetation Prodrome. Plant Biosyst. 2014, 148, 728-814. [CrossRef]

80. Legendre, L.; Legendre, P. Numerical Ecology, 2nd ed.; Elsevier Science BV: Amsterdam, The Netherlands, 1998.

81. Gotelli, N.J.; Graves, G.R. Null Models in Ecology; Smithsonian Institution Press: Washington, DC, USA, 1996.

82. Bajocco, S.; Ricotta, C. Evidence of selective burning in Sardinia (Italy): Which land-cover classes do wildfires prefer? Landscape Ecol. 2008, 23, 241-248. [CrossRef]

83. Manly, B.F.; McDonald, L.L.; Thomas, D.L. Resource Selection by Animals: Statistical Design and Analysis for Field Studies; Chapman \& Hall: London, UK, 1993.

84. Alldredge, J.R.; Thomas, D.L.; McDonald, L.L. Survey and comparison of methods for study of resource selection. J. Agric. Biol. Environ. Stat. 1998, 3, 237-253. [CrossRef]

85. Barreda, V.D.; Palazzesi, L.; Tellería, M.C.; Olivero, E.B.; Raine, J.I.; Forest, F. Early evolution of the angiosperm clade Asteraceae in the Cretaceous of Antarctica. Proc. Natl. Acad. Sci. USA 2015, 112, 10989-10994. [CrossRef] [PubMed]

86. Čuda, J.; Skálová, H.; Janovský, Z.; Pyšek, P. Competition among native and invasive Impatiens species: The roles of environmental factors, population density and life stage. AoB Plants 2015, 7. [CrossRef] [PubMed]

87. Hodgins, K.A.; Bock, D.G.; Hahn, M.A.; Heredia, S.M.; Turner, K.G.; Rieseberg, L.H. Comparative genomics in the Asteraceae reveals little evidence for parallel evolutionary change in invasive taxa. Mol. Ecol. 2015, 24, 2226-2240. [CrossRef]

88. Chen, M.; Yan, T.; Shen, Q.; Lu, X.; Pan, Q.; Huang, Y.; Tang, Y.; Fu, X.; Liu, M.; Jiang, W.; et al. GLANDULAR TRICHOME-SPECIFIC WRKY 1 promotes artemisinin biosynthesis in Artemisia annua. New Phytol. 2017, 214, 304-316. [CrossRef] 
89. Tordoni, E.; Petruzzellis, F.; Nardini, A.; Bacaro, G. Functional Divergence Drives Invasibility of Plant Communities at the Edges of a Resource Availability Gradient. Diversity 2020, 12, 148. [CrossRef]

90. Martini, F.; Galasso, G. Elodea nuttallii (Planc.) H.St.John. In Aggiornamenti Alla Flora Del Friuli Venezia Giulia (Italia Nord-Orientale). Nuova Serie. I (1-40); Martini, F., Ed.; Gortania: Udine, Italy, 2014; Volume 35, pp. $44-45$.

91. Poldini, L. La Vegetazione del Carso Isontino e Triestino; Lint: Trieste, Italy, 1989.

92. Xie, D.; Yu, D.; Yu, L.F.; Liu, C.H. Asexual propagations of introduced exotic macrophytes Elodea nuttallii, Myriophyllum aquaticum, and M. propinquum are improved by nutrient-rich sediments in China. Hydrobiologia 2010, 655, 37-47. [CrossRef]

93. Barrat-Segretain, M.H.; Elger, A.; Sagnes, P.; Puijalon, S. Comparison of three life-history traits of invasive Elodea canadensis Michx. and Elodea nuttallii (Planch.) H. St. John. Aq. Bot. 2002, 74, 299-313. [CrossRef]

94. Simpson, D.A. Displacement of Elodea canadensis Michx by Elodea nuttallii (Planch.) H. St John in the British Isles. Watsonia 1990, 18, 173-177.

95. Barrat-Segretain, M.H. Invasive species in the Rhône River floodplain (France): Replacement of Elodea canadensis Michaux by E. nuttallii St. John in two former river channels. Archiv für Hydrobiologie 2001, 152, 237-251.

96. Larson, D. Non-Indigenous Freshwaters Plants. Patterns, Processes and Risk Evaluation; Swedish University of Agricultural Sciences: Uppsala, Sweden, 2007.

97. Aeschimann, D.; Lauber, K.; Moser, D.M.; Theurillat, J.P. Flora Alpina; Zanichelli: Bologna, Italy, 2004.

98. Li, J.; Ma, M. Seeds over-wintering characteristics of Italian Cocklebur and Stab Cocklebur: Two invasive plants in Xinjiang, China. S. Afr. J. Bot. 2019, 121, 216-218. [CrossRef]

99. Broadfoot, W.M.; Williston, H.L. Flooding Effects on Southern Forests. J. For. 1973, 71, 584-587.

100. Bertoli, M.; Franz, F.; Pastorino, P.; Prearo, M.; Pizzul, E. Seasonal patterns of Phragmites australis breakdown in a karstic freshwater system (Doberdò Lake, Northeast Italy) in relation to water level fluctuations, environmental features, and macrobenthic invertebrate communities. Hydrobiologia 2020, 847, 2123-2140. [CrossRef]

101. Wittenberg, R. (Ed.) An Inventory of Alien Species and Their Threat to Biodiversity and Economy in Switzerland; CABI Bioscience Switzerland Centre report to the Swiss Agency for Environment, Forests and Landscape: Delémont, Switzerland, 2005.

102. Danuso, F.; Zanin, G.; Sartorato, I. A modelling approach for evaluating phenology and adaptation of two congeneric weeds (Bidens frondosa and Bidens tripartita). Ecol. Model. 2012, 243, 33-41. [CrossRef]

103. Pyšek, P.; Chytrý, M.; Pergl, J.; Sádlo, J.; Wild, J. Plant invasions in the Czech Republic: Current state, introduction dynamics, invasive species and invaded habitats. Preslia 2012, 84, 575-629.

104. Wei, C.; Tang, S.; Pan, Y.; Li, X. Plastic responses of invasive Bidens frondosa to water and nitrogen addition. Nordic J. Bot. 2017, 35, 232-239. [CrossRef]

105. Crowe, D.R.; Parker, W.H. Hybridization and agamospermy of Bidens in northwestern Ontario. Taxon 1981, 30, 749-760. [CrossRef]

106. Petrova, A.S.; Vladimirov, V. Two alien species of Bidens (Asteraceae) new to the Bulgarian flora. Phyt. Balc. 2009, 15, 367-371.

107. Nimis, P.L.; Martellos, S.; Moro, A. IL progetto Dryades: Come identificare una pianta, da Gutenberg a Internet. Biol. Italiani 2003, 7, 9-15.

108. Halvorson, W.L.; Guertin, P. Factsheet for: Oxalis stricta L.; USGS Weeds in the West project: Status of Introduced Plants in Southern Arizona Parks; USGS: Tucson, AZ, USA, 2003.

109. Poldini, L.; Vidali, M. Cenosi arbustive nelle Alpi sudorientali (NE-Italia). Coll. Phytosoc. 1995, 24, $141-167$.

110. Freeman, C.C.; Schofield, E.K. Roadside Wildflowers of the Southern Great Plains; University Press of Kansas: Lawrence, KS, USA, 1991.

111. Park, C.M.; Choi, G.H. Study on the Flooding Tolerance of Some Woody Plants for Selecting Useful Revegetation Plants in Lake and Marsh Slopes. J. Korean Environ. Res. Reveg. Technol. 2001, 4, 45-51.

112. Doroftei, M.; Mierlă, M.; Marinov, M. Ecology of some alien plant species in Danube Delta. Ovid. Univ. Ann. Nat. Sci. Biol. Ecol. 2005, 9, 1-4.

113. Takagi, K.; Hioki, Y. Autecology, distributional expansion and negative effects of Amorpha fruticosa L. on a river ecosystem: A case study in the Sendaigawa River, Tottori Prefecture. Landsc. Ecol. Eng. 2013, 9, 175-188. [CrossRef] 
114. Kozuharova, E.; Matkowski, A.; Woźniak, D.; Simeonova, R.; Naychov, Z.; Malainer, C.; Mocan, A.; Nabavi, S.M.; Atanasov, A.G. Amorpha fruticosa-A Noxious Invasive Alien Plant in Europe or a Medicinal Plant against Metabolic Disease? Front. Pharmacol. 2017, 8, 333. [CrossRef]

115. Brigić, A.; Vujčić-Karlo, S.; Kepčija, R.M.; Stančić, Z.; Alegro, A.; Ternjej, I. Taxon specific response of carabids (Coleoptera, Carabidae) and other soil invertebrate taxa on invasive plant Amorpha fruticosa in wetlands. Biol. Invasions 2014, 16, 1497-1514. [CrossRef]

116. Rosenzweig, M.L. Species Diversity in Space and Time; Cambridge University Press: Cambridge, UK, 1995.

117. Catford, J.A.; Daehler, C.C.; Murphy, H.T.; Sheppard, A.W.; Hardesty, B.D.; Westcott, D.A.; Rejmánek, M.; Bellingham, P.J.; Pergl, J.; Horvitz, C.C.; et al. The intermediate disturbance hypothesis and plant invasions: Implications for species richness and management. Persp. Plant Ecol. Evol. Syst. 2012, 14, 231-241. [CrossRef]

118. Petruzzellis, F.; Nardini, A.; Savi, T.; Tonet, V.; Castello, M.; Bacaro, G. Less safety for more efficiency: Water relations and hydraulics of the invasive tree Ailanthus altissima (Mill.) Swingle compared with native Fraxinus ornus L. Tree Physiol. 2019, 39, 76-87. [CrossRef]

119. Gallien, L.; Mazel, F.; Lavergne, S.; Renaud, J.; Douzet, R.; Thuiller, W. Contrasting the effects of environment, dispersal and biotic interactions to explain the distribution of invasive plants in alpine communities. Biol. Invasions 2014, 17, 1407-1423. [CrossRef] [PubMed]

(C) 2020 by the authors. Licensee MDPI, Basel, Switzerland. This article is an open access article distributed under the terms and conditions of the Creative Commons Attribution (CC BY) license (http://creativecommons.org/licenses/by/4.0/). 